\title{
Diet and histomorphological study of the gastrointestinal system of Melanophryniscus klappenbachi (Anura: bufonidae)
}

\author{
Arias, A.M. ${ }^{1}$; Larrea, D.D. ${ }^{2}$; Céspedez, J.A.'; F. Quintana, C. ; Olea, G.B. ${ }^{3,4,5}$ \\ ${ }^{1,2}$ Univ. Nac. Nordeste, Fac. Cs. Exactas, Depto. Biología, Corrientes, Argentina; \\ ${ }^{3}$ Univ. Nac. Nordeste, Fac. Medicina, Corrientes; ${ }^{4}$ Univ. Cat. Santa Fe, Depto. Cs. Básicas, \\ Reconquista; Santa Fe, Argentina; ${ }^{5}$ Univ. Nac. Chaco Austral, Dep. Cs. Vet., Chaco, Argentina. \\ E-mail: aniarias@hotmail.es
}

\begin{abstract}
Arias, A.M.; Larrea, D.D.; Céspedez, J.A.; F.Quintana, C.; Olea, G.B.: Diet and histomorphological study of the gastrointestinal system of Melanophryniscus klappenbachi (Anura: bufonidae). Rev. Vet. 32: 2, 131-137, 2021. The diet and histomorphology of the digestive tract of Melanophryniscus klappenbachi were determined by the analysis of adult and juvenile specimens collected in a private field in Bermejo department, Chaco, Argentina. The sampling was carried out monthly from March to June 2015. 29 specimens were collected, measured, sexed, and dissected for the obtainment of the digestive content and histological samples. The results showed a high tendency towards my rmecophagy; more than $95 \%$ of the recovered prey items were identified as ants. The histomorphology of the gastrointestinal system consisted of the main four layers of tissue observed in vertebrates: mucosa, submucosa, muscular, and serosa. This study constitutes a contribution to the knowledge of biology and the natural history of anurans of the Bufonidae family, especially the genus Melanophryniscus, which currently receives a great amount of attention regarding its conservation status.
\end{abstract}

Key words: histology of digestive tract, Klappenbach's frogs, my rmecophagy.

\begin{abstract}
Resumen
Arias, A.M.; Larrea, D.D.; Céspedez, J.A.; F.Quintana, C.; Olea, G.B.: Estudio dietario e histomorfológico del sistema gastrointestinal de Melanophryniscus klappenbachi (Anura: bufonidae). Rev. Vet. 32: 2, 131-137, 2021. La dieta y la morfohistología del tracto digestivo de Melanophryniscus klappenbachi fueron determinadas a partir del análisis de ejemplares adultos y juveniles colectados en un campo privado localizado en el departamento de Bermejo, en la provincia de Chaco, Argentina. El muestreo fue realizado mensualmente entre marzo y junio del 2015. Se analizó un total de 29 ejemplares que fueron disecados para la obtención del contenido gastrointestinal y de las secciones histológicas a preparar. Como resultado, se encontró una tendencia hacia la mirmecofagia, conformando los Formícidos más del $95 \%$ de los ítems presa recuperados de los especímenes. La morfo-histología del sistema gastrointestinal presentó las cuatro capas de tejido principales observadas en vertebrados: mucosa, submucosa, muscular externa y serosa o adventicia. Este estudio constituye un aporte al conocimiento de la biología e historia natural tanto de los anuros en general, como de los bufónidos del género Melanophryniscus en particular, el cual recibe actualmente gran atención respecto a su conservación.
\end{abstract}

Palabras clave: histología del tracto digestivo, ranas de Klappenbach, mirmecófaga.

\section{INTRODUCTION}

Amphibians have a significant role as a study model in physiology, and this group is a standard model for the study of many biological processes. However, relatively few studies have been carried out on the amphibian gastrointestinal tract ${ }^{16}$. Some reports are investigating the gastrointestinal epithelial transformation from the larval to adult type and apoptosis ${ }^{21,22}$. Additionally, histological and histochemical changes in the digestive tract of Ceratophrys ornata and Xenopus laevis during metamorphic climax were reported ${ }^{18}$.

In general, studies related to the digestive system were carried out on reptiles, birds, and mammals. But the cell renewal system of the adult epithelium in the amphibian stomach is similar to the mammalian stomach, where cell proliferation is localized in the neck region of gastric glands. Therefore, the amphibian digestive tract serves as a model system for studying mammalian organ regeneration. Nonetheless, there are few 
studies about the structure of the gastrointestinal tract in amphibians $1,2,8,16,20,25,27,31,34$.

The genus Melanophryniscus, is distributed from the center and southeast of Brazil, south of Bolivia, Paraguay, Uruguay, and the north and center of Argentina (Bol. Asoc. Herpet 12: 71-76) to the savannas of Buenos Aires ${ }^{23}$. There are brief descriptions of the diets of Melanophryniscus moreirae and M. stelzneri. There is also a description of the diet of M. montevidensis ${ }^{32}$, a Uruguayan species of the genus, that relates the ant content in the diet to the production of skin alkaloids ${ }^{9}$

Some authors described the diet of three populations of $M$. rubriventris ${ }^{4}$ in Argentina. Regionally, described and analyzed the diet of $M$. cupreuscapularis in comparison to other species ${ }^{15,16}$. For M. klappenbachi, there is knowledge about the main alkaloids present in the species skin and a general description of its diet ${ }^{11}$.

Due to the lack of studies on the digestive system of anurans, particularly those that relate its structure with dietary habits, this work aimed to study the diet and the histomorphological structure of the gastrointestinal tract of $M$. klappenbachi with the hope of contributing to the natural history of anurans in general and specially bufonids of this genus.

\section{MATERIALS AND METHODS}

\section{Collection}

We collected 29 adult and juvenile specimens of $M$. klappenbachi of March a June 2015 in a private field located $20 \mathrm{~km}$ from the entrance of the "Las Palmas" locality, in Bermejo department, Chaco province, Argentina. We added the specimens to the Herpetological Collection of the National University of the Northeast (UNNEC), numbered as follows: UNNEC 13081 a 13109.

The site is characterized by remnants of Spinello and algarrobillo woodlands associated with palm trees and grasslands with flood zones, typical of Oriental Semihumid Chaco. The field is near the Paraná River, surrounded by a degraded forest.

The methodology consisted of "Surveys at breeding sites" ${ }^{32}$, with monthly surveys carried out between March and June 2015. We took the samples manually, without distinction of sex or size. We transferred the specimens to the laboratory in plastic bags and dampened containers.

We euthanized the specimens using benzocaine hydrochloride $250 \mathrm{mg} / \mathrm{l}$, standard IACUC protocol, and CICUAL Fmed-UNNE 004/18. Then, we fixated the specimens with Bouin solution and preserved them in $10 \%$ formaldehyde. We measured each specimen with a digital caliper (0.01 $\mathrm{mm}$ accuracy); the measures taken were: snout-vent length (SVL) and mouth width (MW).

\section{Anatomical analysis}

We performed an incision on the ventral region and extracted the complete digestive tract. We measured the tract using a digital caliper $(0.01 \mathrm{~mm}$ accuracy). The measures taken were the width and length of the stomach and intestines and the total length of the digestive tract (TLD).

Later, we fixated the tracts with Bouin solution and preserved them in $10 \%$ buffered formaldehyde. Then, we dehydrated the samples, included them in paraffin, cut them in $6 \mu \mathrm{m}$ sections and stained them with hematoxylin and eosin (HE), periodic acid-Schiff (PAS) and Gömöri trichrome stains. We observed and photographed the samples with a Leica trinocular microscope (DME model). We determined the sex of each specimen by direct observation of the gonads. Then, we analyzed the digestive content under a stereomicroscope.

We dissected the specimens and cut their digestive tracts for observation under a Scanning Electron Microscope (SEM). We dehydrated, dried, and metalized the sections with gold.

We carried out the observations with a JEOL JSM$5800 \mathrm{LV}$ microscope belonging to the Scanning Electron Microscopy Service of the General Secretariat of Science and Technology (SGCyT) of the National University of the Northeast (UNNE).

\section{Data analysis}

We identified each prey item to the lowest possible taxonomic level. We calculated the trophic diversity of the species using the Shannon-Weaver diversity in$\operatorname{dex}^{33}$. We compared the size of the specimens in terms of SVL, MW, and TLD between males and females using the Mann-Whitney U Test. We determined the mean number of prey per stomach for the complete sample and each sex.

We determined the Spearman (r) correlation coefficient for SVL-MW, SVL-TLD, and SVL-number of prey per stomach. We carried out every analysis using the statistical analysis programs Past ${ }^{19}$ and Infostat ${ }^{12}$ and the spreadsheet Microsoft Excel.

\section{RESULTS}

\section{Diet}

We captured a total of 29 specimens of March a June 2015 . We only considered adult specimens (19 females, 8 males) with identifiable stomach or intestine content. In the case of juvenile specimens, only their histomorphology was taken into account since they did not present gastro-intestinal content at the time of capture.

The diet consisted of 737 items classified into 6 prey categories (Table 1) and was numerically dominated by ants. Additionally, ants were the most frequent prey category, found in all analyzed specimens $(100 \%)$

The mean number of prey per stomach was $27( \pm$ $25), 26( \pm 24)$ for males, and $29( \pm 27)$ for females. We did not observe significant differences in the number of prey per stomach between sexes (Mann-Whitney U Test $=109.00 ; n=27 ; P=0.95$ ).

The trophic diversity was 0.43 , according to the Shannon-Weaver index (0.48 for females, 0.24 for 
Table l. Types of prey found in the gastrointestinal tracts of 29 specimens of Melanophryniscus klappenbachi capture on March to June 2015 in Bermejo, Chaco, Argentina.

\begin{tabular}{lcccc}
\hline prey category & $\mathrm{n}$ & $\mathrm{f}(\%)$ & $\mathrm{fa}$ & $\mathrm{FO}(\%)$ \\
\hline ARTHROPODA & & & & \\
INSECTA & & & & \\
HYMENOPTERA & & & & \\
$\quad$ Formicidae & & & & \\
$\quad \begin{array}{l}\text { Myrmicinae } \\
\text { Pheidole aberrans }\end{array}$ & 49 & $6,65 \%$ & 7 & $25,93 \%$ \\
$\quad \begin{array}{l}\text { Solenopsis invicta } \\
\text { Acromyrmex sp. }\end{array}$ & 660 & $89,55 \%$ & 26 & $96,30 \%$ \\
COLEOPTERA & 1 & $0,14 \%$ & 1 & $3,70 \%$ \\
$\quad$ Curculionidae & 3 & $0,41 \%$ & 3 & $11,11 \%$ \\
$\begin{array}{l}\text { DIPTERA } \\
\text { (n.i.) }\end{array}$ & 1 & $0,14 \%$ & 1 & $3,70 \%$ \\
ARACHNIDA & & & & \\
acari & 23 & $3,12 \%$ & 2 & $7,41 \%$ \\
Total Prey Items & 737 & & & \\
\hline
\end{tabular}

$\mathrm{n}=$ number of prey per category, $\mathrm{f}(\%)=$ percentage of each category in the overall sample, fa $=$ number of gastrointestinal tracts with each category, and $\mathrm{FO}(\%)=$ frequency of occurrence.

males). We found no significant differences between the diets of males and females of this species (MannWhitney $\mathrm{U}$ Test $=97.00 ; n=27 ; P=0.47$ ).

\section{Gastrointestinal morphometry}

The gastrointestinal tract of $M$. klappenbachi was divided into three main regions: stomach, small intestine, and large intestine (Figure 1). The mean MW was $7.8 \mathrm{~mm}( \pm 0.51)$ for males $(n=8)$ and $8.08 \mathrm{~mm}( \pm 0.54)$ for females $(n=19)$. The mean SVL was $28.34 \mathrm{~mm}( \pm$ $1.3)$ for males and $29.52 \mathrm{~mm}( \pm 1.88)$ for females.

The mean TDL was $62.83 \mathrm{~mm}( \pm 8.92), 61.32$ $\mathrm{mm}( \pm 5.29)$ for males, and $64.95 \mathrm{~mm}( \pm 8.40)$ for females. We did not find significant differences in SVL (Mann-Whitney U Test $=74.00 ; n=27 ; P=0.08$ ), MW
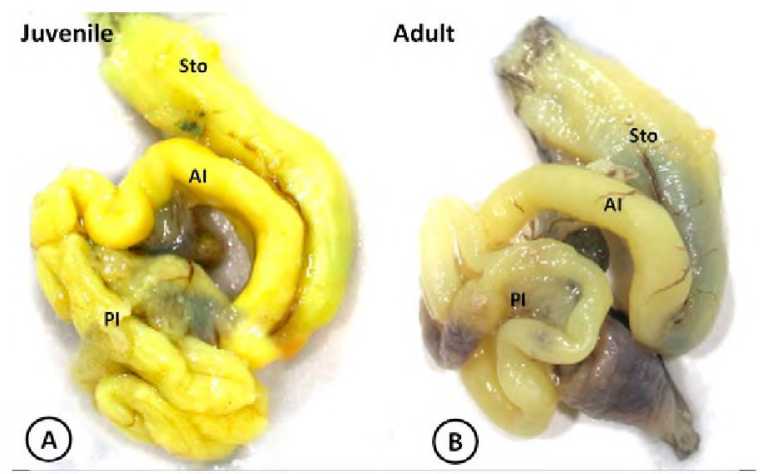

Figure 1. Macro-photography of the digestive system of M. klappenbachi. A: juvenile. B: adult. Magnification: X4. References: Sto: stomach; $A I$ : anterior intestine; PI: posterior intestine.
(Mann-Whitney U Test $=77.00 ; n=27 ; P=0.11$ ) or TDL (Mann-Whitney U Test $=89.00 ; n=27 ; P=0.38$ ) between males and females. We found a positive and significant correlation between the SVL $(r=0.56)$ and the MW ( $\mathrm{r}=0.56)$, with $P=0.002$ and $n=27$. We also found a positive and significant correlation between SVL $(r=0.64)$ and TLD $(\mathrm{r}=0.64)$, with $P=0.0004$ and $n=27$. We found no association between SVL and the number of prey per stomach $(\mathrm{r}=0.013)$, with $P=0.95$ and $n=27$.

\section{Histomorphology}

The histological structure of the digestive tract in both juveniles (Fig. 2, 4 and 5) and adults (Figs. 3 and 6 ) is composed of the typical layers observed in vertebrates: mucosa, submucosa, external muscular and serous (Figs. $2 \mathrm{~A}$ and $3 \mathrm{~A}$ ).

\section{Stomach}

In the stomach, juveniles, and adults, the mucosa had gastric folds and a simple layer of epithelium lining composed of mucous cells in the spine. It has gastric
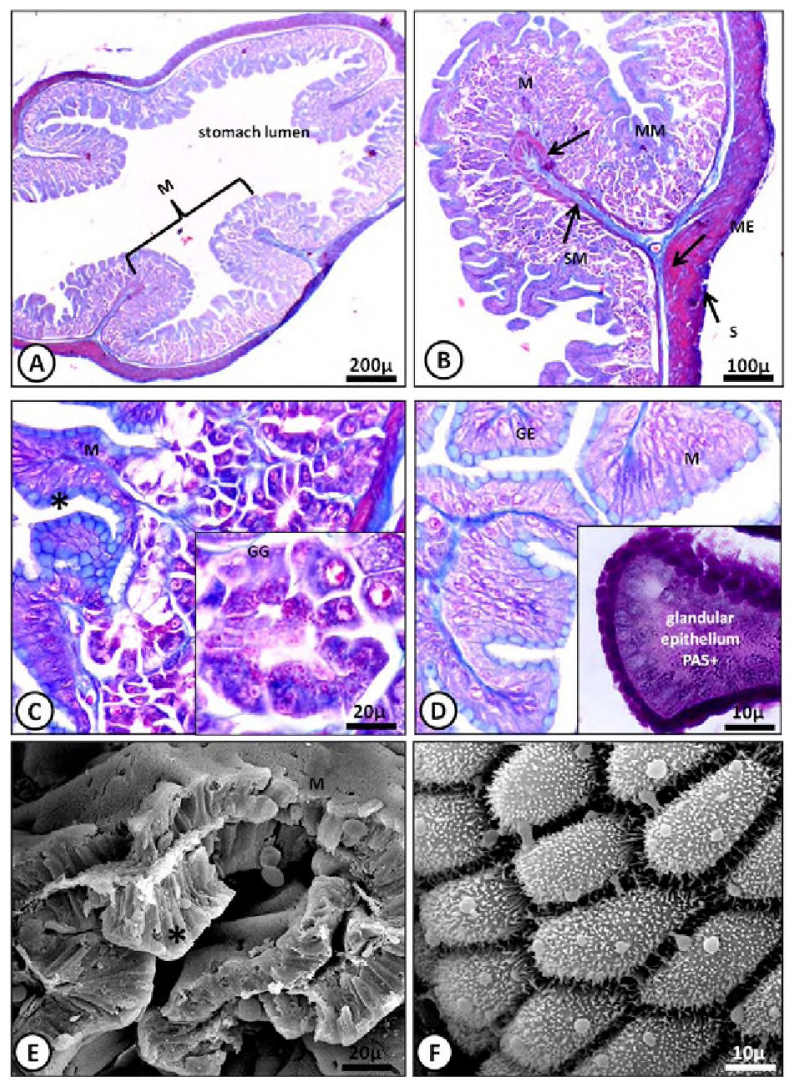

Figure 2. Micrograph of the juvenile stomach of $M$. klappenbachi. A) Layers of the stomach; M, mucosa; MM, muscularis mucosae; SM, submucosa; ME, muscular; S, serosa. Gomori trichrome stain. B) Mucosa. GE, glandular epithelium; GG, gastric glands. Gomori trichrome stain. Cells and gastric glands. C) Glandular epithelium (*) and gastric glands. Gomori trichrome stain. D) Positive PAS reaction for apical portions of mucous. E-F) SEM microphotographs showing in detail the gastric folds $(\mathrm{E})$ and mucosal epithelial cells $(\mathrm{F})$. 
glands located at the base of the barrel-shaped grooves called gastric fossae (Fig. $2 \mathrm{~A}$ and $3 \mathrm{~B}$ ). The apical domain of epithelial cells was found to be acidophilous and exhibited a strong positive reaction for PAS (Fig. $2 \mathrm{D}, 3 \mathrm{C}$ )

The mucosa is separated from the submucosa by a muscular layer of the mucosa. The gastric glands were structured as simple tubular glands, often branched to the lower portion of the gland and composed of mucous cells of the neck, located mainly in the neck region (Fig. 2 C, 3 B and D). Through SEM, it was possible to observe the gastric ostioles. Superficial mucous cells, such as neck cells, showed bright purple staining after treatment with PAS, indicating the presence of glycoproteins.

The submucosa was formed by loose connective tissue rich in blood vessels, as evidenced by strong staining after treatment with Gömöri trichrome staining; however, we did not find glands in this region. The external muscle was also made of smooth muscle tissue. The serosa was observed as a thin layer of loose connective tissue with some blood vessels, covered with mesothelium.

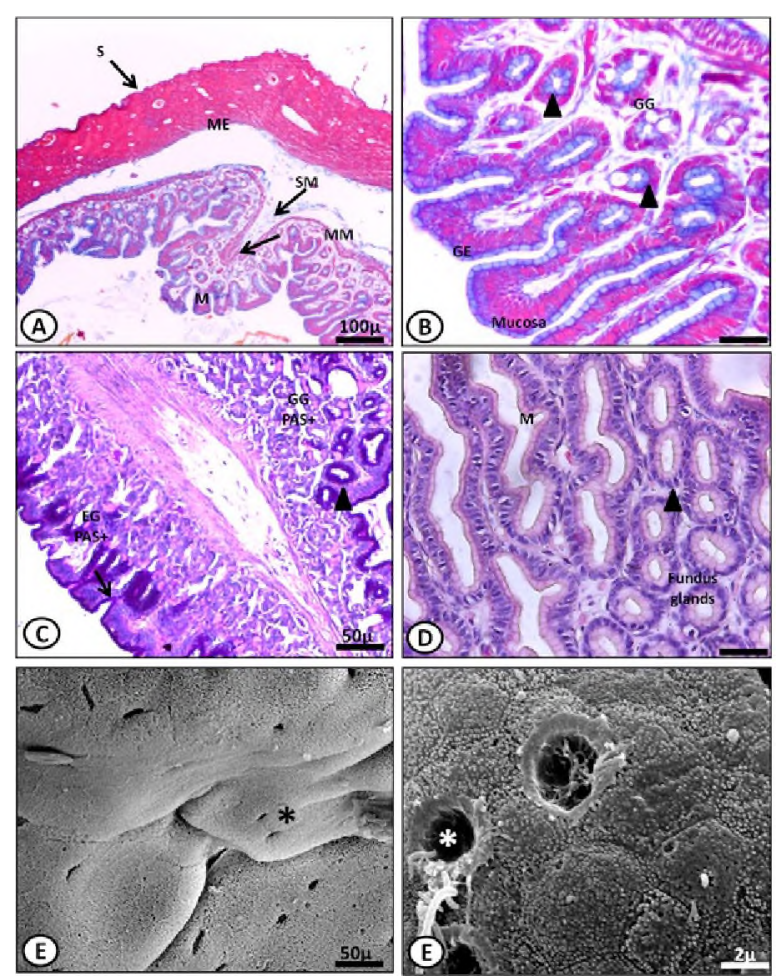

Figure 3. Micrograph of the stomach adult of M. klappenbachi. A) Layers of the stomach; M, mucosa; MM, muscularis mucosa; SM, submucosa; ME, muscular, S, serosa. Gomori trichrome stain. B) Mucosa. GE, glandular epithelium; GG, gastric glands. Gomori trichrome stain. Cells and gastric glands. C) Positive PAS reaction for apical portions of mucous. D) Glandular epithelium and gastric glands. HE stains. E-F) SEM microphotographs showing in detail the gastric folds (E) and mucosal epithelial cells and ostioles (F).

\section{Intestine}

The mucosa of the intestine (thin and thick) of both juveniles and adults showed several high longitudinal folds called intestinal villi (Fig. $5 \mathrm{E}$ ). These villi were composed of columnar enterocytes with microvilli on their apical surface (Fig. 4 B, 5 E). We also found a large number of goblet cells in this epithelium.

These cells showed strong staining after treatment with PAS (Fig. 4 and 6 D), indicating the presence of glycoproteins, a product of the secretion of these unicellular glands. The submucosa was composed of loose connective tissue with some vascularization. The muscle showed moderate development in the sections. The outermost layer, the serosa, was composed of a thin layer of connective tissue.

The difference between juveniles and adults in the intestine was given at the level of abundance of goblet cells, the number in the region of the large intestine of the juveniles being greater, while in adults, that difference was not evident (Figure 4 and 6).

\section{DISCUSSION}

The analysis carried out in this study revealed that in $M$. klappenbachi, the preponderance of hymenopterans of the family Formicidae is significant, constituting more than $95 \%$ of the prey sample. These ants belonged to three species of the subfamily Myrmicinae. These taxa were followed in abundance by mites.

Analyzed feces from $M$. montevidensis, revealing the presence of ants and mites ${ }^{32}$. Observed the preponderance of ants in the diets of $M$. cupreuscapularis
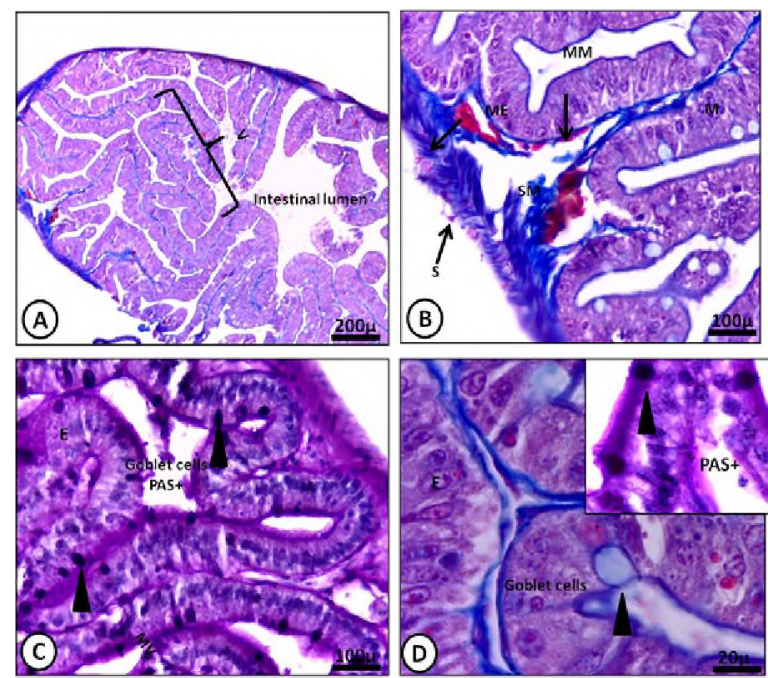

Figure 4. A-D) Light micrograph of the anterior intestine of M. klappenbachi (juvenile). A) Layers of the intestine; M, mucosa; SM, submucosa; ME, muscular, $\mathrm{S}$, serosa, Mucosa folds or villi (V). Gomori trichrome stain. B) M, mucosa; SM, submucosa; L, lacteal. Gomori trichrome stain C) Intestine layers and components; MV, microvilli; E, enterocytes; Goblet cells positive PAS. PAS stain. D) Positive PAS reaction for globlet cells. Gomori trichrome and PAS stain. 
and $M$. klappenbachi ${ }^{10}$. Some authors described and analyzed the diet of $M$. cupreuscapularis, comparing it with other bufonids ${ }^{14,15}$. Finally, in 2013 carried out a study about the diet of $M$. devincenzii, also showing the predominance of mites followed by ants ${ }^{5}$.

Taking into account numerical frequencies, we consider M. Klappenbachi an ant specialist. Matching the results from numerous previous studies that maintain that specialist foragers use active search for the capture of their prey and prefer small and hard prey like ants and beetles ${ }^{24}$, we consider $M$. klappenbachi an active predator since these toads pursue their prey and demonstrate a clear tendency towards my rmecophagy.

In addition to the analyzed prey, there was also plant material found in the alimentary tracts, but this was not included in the study since its ingestion was deemed accidental. Observed that a certain amount of the stomach contents of Bombina variegate (29.82\%) consisted of plant fragments and suggested, too, that they were eaten by accident ${ }^{19}$.

The same accidental ingestion was postulated for $M$. devincenzii ${ }^{5}$. Some authors considered that the
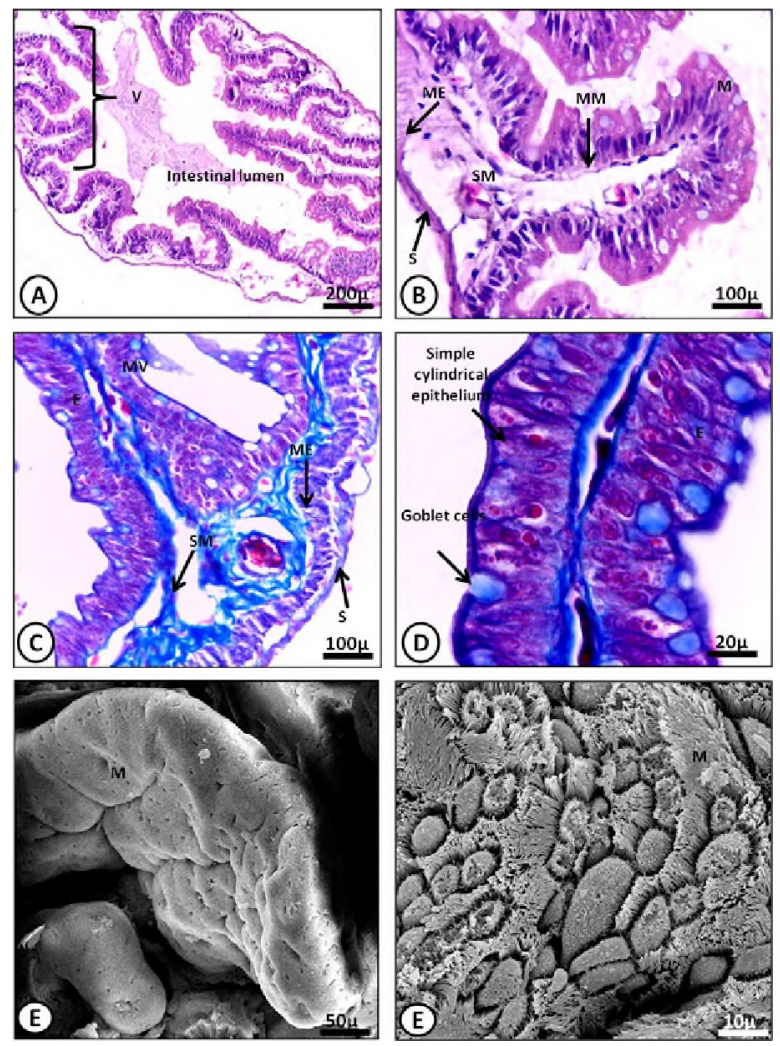

Figure 5. A-D) Light micrograph of the posterior intestine of $M$. klappenbachi (juvenile). A) Layers of the intestine; $M$, mucosa; SM, submucosa; ME, muscular, $\mathrm{S}$, serosa, Mucosa folds, or villi (V). HE stains. B) Detail of Mucosa fold. M, mucosa; SM, submucosa. HE stains C) Intestine layers and components; MV, microvilli; E, enterocytes; Globet cells. Gomori trichrome stain. D) Detail goblet cells and enterocytes Gomori trichrome stain. E-F) SEM microphotographs showing in detail the intestinal folds (E) and mucosal epithelial cells and microvilli $(\mathrm{F})$. ingestion of plant fragments is helpful for anurans in terms of gut parasites elimination and nutritional and even hydric contribution ${ }^{3}$

Studies regarding the intersexual differences in the diets of anurans are scarce due to the difficulty of capturing females of many species ${ }^{27}$. This variation between sexes could reflect the different requirements of each sex ${ }^{13,29}$ or different foraging strategies ${ }^{6}$ since males need more energy for vocalization and territorial defense, and females need energy for egg production during the breeding season ${ }^{30}$. In the present work a significant difference between both sexes could not be found.

The gastrointestinal tract showed the typical structure observed in vertebrates; in the same way, the typical cell and mucosa arrangements were observed. Some authors have presented similar results in Rhinella icterica ${ }^{28}$ and Hyla orientalis ${ }^{1}$

These results provide a basis for the analysis of the gastrointestinal histomorphology and leave an open path to a more specific study regarding each region of the digestive system.
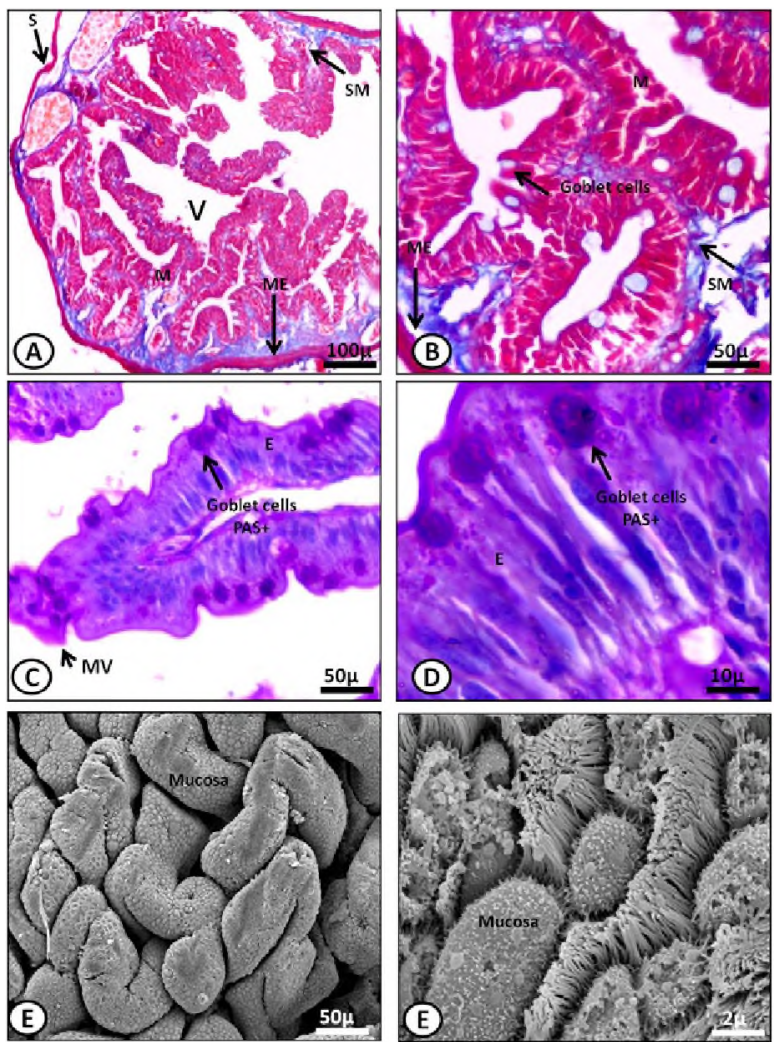

Figure 6. A-D) Light micrograph of the anterior intestine $(\mathrm{A}, \mathrm{B})$ and posterior intestine $(\mathrm{C}, \mathrm{D})$ of $M$. klappenbachi (adult). A) Layers of the intestine; $\mathrm{M}$, mucosa; SM, submucosa; ME, muscular, S, serosa, Mucosa folds, or villi (V). Gomori trichrome stain. B) Detail of Mucosa fold. M, mucosa; SM, submucosa. Gomori trichrome stain. C) Details fold intestinal; MV, microvilli; E, enterocy tes; Goblet cells. PAS stain. D) Detail goblet cells and enterocytes. PAS stain. E-F) SEM microphotographs showing in detail the intestinal folds (E) and mucosal epithelial cells and microvilli (F). 
The PAS staining was positive for the gastric glands and apical portions of the mucous stomach cells, and the goblet cells present in the intestines, due to the presence of glycoproteins. These results concur with previous observations in other amphibians, Triturus carnifex ${ }^{27}$, Bufo viridis ${ }^{26}$, Hyla orientalis ${ }^{1}$, Rana aurora ${ }^{17}$ and in some fish ${ }^{12}$ reptiles ${ }^{7}$ and mammals ${ }^{35}$.

These glycoconjugates are of great importance since they possess a significant role that includes maintaining the moisture of the tissues, lubrication, and reduction of mechanical friction, including the friction produced by feces when leaving the alimentary canal ${ }^{1}$, and the protection against chemicals and pathogens.

We consider that the data provided by this work is of importance as a basis for future studies that include both the trophic analysis of $M$. klappenbachi and its role in the obtainment and presentation of skin alkaloids ${ }^{10}$, not only for this species but for other anurans of the genus Melanophryniscus as well.

This work also characterizes the general histological structure of the gastrointestinal tract of the species and aims to serve as a foundation for future studies, both comparative and specific.

Acknowledgments. To the research projects of the General Secretary of Science and Technology of the National University of the Northeast (SGCyT-UNNE) (PI 16F013: Natural History of amphibians and reptiles of north-eastern Argentina, Director: Céspedez, Jorge).

\section{REFERENCES}

1. Akat E, Arikan H, Göçmen, B. 2014. Histochemical and biometric study of the gastrointestinal system of Hyla orientalis (Bedriaga, 1890) (Anura, Hylidae). Europ J Histochem 58: 291-295.

2. Akat E. 2019. Histological and histochemical aspects of the digestive tract of Lyciasalamandra billae arikani Göçmen \& Akman, 2012 (Urodela: Salamandridae). Acta Zool Bulg 71: 525-529.

3. Anderson AM, Haukos DA, Anderson J. 1999. Diet composition of three anurans from the playa Wetlands of Northwest Texas. Copeia 2: 515-520.

4. Bonansea MI, Vaira M. 2007. Geographic variation of the diet of Melanophryniscus rubriventris (Anura: Bufonidae) in Northwestern Argentina. J Herpet 41: 231-236.

5. Bortolini SV, Maneyro R, Coppes F, Zanella N. 2013. Diet of Melanophryniscus devincenzii (Anu ra: Bufonidae) from Parque Municipal de Sertão, Rio Grande do Sul, Brazil. The Herpet $J$ 23: 115-119.

6. Brasileiro CA, Marins M, Sazima I. 2010. Feeding ecology of Thoropa taophora (Anura: Cycloramphidae) on a rocky seashore in southeastern Brazil. South Am J Herpetol 5: 181-188.

7. Çakici O, Akat E. 2013. Some histomorphological and histochemical characteristics of the digestive tract of the snake-eyed lizard, Ophisops elegans Menetries, 1832 (Squamata: Lacertidae). North-Western J Zool 9: 257-263.
8. Cramp RL, Franklin CE. 2005. Arousal and re-feeding rapidly restores digestive tract morphology following aestivation in green-striped burrowing frogs. Comp Biochem \& Physiol-Part A: Molec \& Integrat Physiol 142: 451-460.

9. Daly JW et al. 2008. Indolizidine 239 Q and quinolizidine 275I. Major alkaloids in two Argentinian bufonid toads (Melanophryniscus). Toxicon 52: 858-870.

10. Di Rienzo JA et al. 2015. InfoStat versión 2015. Grupo InfoStat, FCA, Universidad Nacional de Córdoba, Argentina

11. Domeneghini C, Arrighi S, Radaelli G, Bosia G, Veggetti A. 2005. Histochemical analysis of glycoconjugate secretion in the alimentary canal of Anguilla anguilla $\mathrm{L}$. Acta Histochem 106: 477-487.

12. Donnelly MA. 1991. Feeding patterns of the strawberry poison frog, Dendrobates pumilio (Anura: Dendrobatidae). Copeia 1991: 723-730.

13. Duré M, Kehr AI. 2006. Melanophryniscus cupreuscap ularis (NCN). Diet, short notes. Herpetol Rev 37: 338.

14. Duré MI, Kehr AI, Schaefer EF. 2009. Niche overlap and resource partitioning among five sympatric bufonids (Anura, Bufonidae) from northeastern Argentina. Phyllomedusa 8: 27-39.

15. Feder ME. 1992. A perspective on the environmental physiology of the amphibians. In Feder M.E., Burggren W.W. (Eds.), Environmental Physiology of the Amphibians, The University of Chicago Press, Chicago, p.1-6.

16. Ferri D, Liquori GE, Natale L, Santarelli G, Scillitani G. 2001. Mucin histochemistry of the digestive tract of the red-legged frog Rana aurora. Acta Histochem 103: 225 237.

17. Fry AE, Kaltenbach JC. 1999. Histology and lectin binding patterns in the digestive tract of the carnivorous larvae of the Anuran, Ceratophrys ornata. JMorphol 241: 19-32

18. Guiurcă D, Zaharia L. 2005. Data regarding the trophic spectrum of some population of Bombina variegata from Bacău county, North-Western. J Zool 1: 15-24.

19. Hammer O, Harper DA, Ryan PD. 2001. Paleontological statistics software package for education and data analysis. Palaeontol Electron 4: 1-9.

20. Ishizuya OA, Ueda S. 1996. Apoptosis and cell proliferation in the Xenopus small intestine during metamorphosis. Cell \& Tissue Research 286: 467-476.

21. Kaltenbach JC, Fry AE, Colpitts KM, Faszewski EE. 2012. A poptosis in the digestive tract of herbivorous Rana pipiens larvae and carnivorous Ceratophrys ornata larvae: an immunohistochemical study. J Morphology 273 : 103-108.

22. Kwet A, Maneyro R, Zillikens A, Mebs D. 2005. Advertisement calls of Melanophryniscus dorsalis (Mertens, 1933) and M. montevidensis (Philippi, 1902), two parapatric species from southern Brazil and Uruguay, with comments on morphological variation in the Melanophryniscus stelzneri group (Anura: Bufonidae). Salamandra 41: $1-18$.

23. Lajmanovich RC. 1995. Relaciones tróficas de bufónidos (Anura, Buronidae) en ambientes del Río Paraná, Argentina. Alytes 13: 87-103.

24. Liquori GE Scillitani G, Mastrodonato M, Ferri D. 2002. Histochemical investigations on the secretory cells 
in the oesophagogastric tract of the Eurasian green toad, Bufo viridis. Histochem J 34: 517-524.

25. Liquori GE, Mastrodonato M, Zizza S, Ferri D. 2007. Glycoconjugate histochemistry of the digestive tract of Triturus carnifex (Amphibia, Caudata). J Molec Histol 38:191-199.

26. López JA, Scarabotti PA, Medrano MC, Ghirardi R. 2009. Is the red spoted green frog Hypsiboas punctatus (Anura: Hylidae) selecting its preys? The importance of prey availability. Rev de Biol Trop 3: 847-857.

27. Machado SC, Pelli AA, Abidu FM, Debrito GL. 2014. Histochemical and immunohistochemical analysis of the stomach of Rhinella icterica (Anura, Bufonidae). J Histol 2014: 1-8.

28. Maneyro R, Naya DE, Rosa I, Canavero A, Camargo A. 2004. Diet of the South American frog Leptodactylus ocellatus (Anura, Leptodactylidae) in Uruguay. Iheringia, Série Zoologia 94: 57-61.

29. Maneyro R, Kwet A. 2008. Amphibians in the border region between Uruguay and Brazil: updated species list with comments on taxonomy and natural history (Part I: Bufonidae). Stutgarter Beiträge zur Naturkunde 1: 95-121.
30. Mebs D, Pogoda W, Maneyro R, Kwet A. 2005. Studies on the poisonous skin secretion of individual red bellied toads, Melanophryniscus montevidensis (Anura, Bufonidae), from Uruguay. Toxicon 46: 641-650.

31. Muikham I, Srakaew N, Chatchavalvanich K, Chumnanpuen P. 2016. Microanatomy of the digestive system of Supachai's caecilian, Ichthyophis supachaii Taylor, 1960 (Amphibia: Gymnophiona). Acta Zoologica 98: 252-270.

32. Scott NJ, Woodward BD. 2001. Relevamientos de lugares de reproducción. En: Medición y monitoreo de la diversidad biológica, métodos estandarizados para anfibios, Heyer W.R. el al. Ed. Univ.Patagonia, Chubut, p. 113-117.

33. Shannon CE, Weaver W. 1949. The mathematical theory of communication. Univ. Illinois Press, Urbana, Illinois Press, 125 p.

34. Suganuma T et al. 1981. Comparative histochemical study of alimentary tracts with reference to the mucous neck cells of the stomach. Am J Anatomy 161: 219-238.

35. Taigen T, Wells K. 1985. Energetics of vocalization by an anuran amphibian (Hyla versicolor). Journal of Comparaive Physiology. Biochemical, systemic, and environmental physiology 2: 163-170.

\section{Revista Veterinaria obtuvo el máximo nivel de categorización del CAICYT-CONICET}

Tras el pertinente proceso de evaluación según criterios de calidad editorial, en setiembre de 2005 CAICYT-CONICET ha clasificado a nuestra publicación con Categoría 1 (nivel superior de excelencia), con lo cual pasa a integrar el Catálogo Latindex (folio 14022). La Dirección de Revista veterinaria agradece a quienes colaboraron para obtener tan importante distinción.

Ver: http://www.latindex.unam.mx/busquedas/catalogotitulo.html 